\title{
Malaysian Industrial Relations at Century's Turn: Vision 2020 or a Spectre of the Past?
}

\author{
Patricia Todd \\ University of Western Australia \\ David Peetz \\ Griffith University
}

\begin{abstract}
Malaysia's industrial relations (IR) has been characterised by extensive State control guaranteeing a high level of managerial prerogative within the workplace, minimal overt conflict and very little bargaining power for labour. These arrangements were an integral component of the package to attract investors when Malaysia's industrialisation strategy focused on low-cost, export-oriented industries. Since then, however, Malaysia has adopted the goal of developed country status by 2020 and embarked on a higher value-added, more capital-intensive industrialisation strategy. This paper analyses current Malaysian IR at the workplace level posing the question as to whether the economic progress towards 'Vision 2020' is being accompanied by a transformation of Malaysia's IR. It will be seen that there is evidence of substantial growth in training, the implementation of multiskilling in some workplaces as well as isolated instances of some 'lean production' practices. Fundamental change however is not occurring, workers remain excluded from the decision making process both within and outside the workplace.
\end{abstract}

\section{Introduction}

Malaysia's industrial relations (IR) has been characterised by extensive State control guaranteeing a high level of managerial prerogative within the workplace, minimal overt conflict and very little bargaining power for labour (Jomo and Todd 1994; Arudsothy and Littler 1993; Ariffin 1997). These arrangements were an integral component of the package to attract investors when Malaysia's industrialisation strategy focused on low-cost, exportoriented industries. Since then, however, Malaysia has adopted the goal of developed country status by 2020 and embarked on a higher value-added, more capital-intensive industrialisation strategy. Might this be expected to lead to changes both in the production mode and the IR/HR policies and practices? To increase productivity one might expect to see some movement away from labour-intensive mass production and the concomitant 'Old IR' (low wage de-skilled labour allocated to a single task, centralised decision-making by management, and limited investment in occupational health and safety and training) to a 'flexible' production model and the accompanying 'New IR' (employee participation in decision-making, multi-skilled employees grouped into semi-autonomous work teams moving between tasks, the provision of ongoing targeted training, mutual commitment between management and workers reflected in employment security, co-operative labour relations and high safety standards) (Kochan, Katz and McKersie 1986; Appelbaum and Batt 1994; Piore and Sabel 1984; Kitay 1997).

Deyo (1995a) explored this issue within Thai workplaces and concluded that in much of the country flexible production techniques were not being introduced, and companies were relying predominantly on cost-cutting strategies to be competitive. Companies adopting flexible production systems were doing so within an autocratic management environment, their implementation of IR/HR reforms were only partial and did not include substantial change in the level of employee participation and involvement. Deyo (1995b) attributed this apparent paradox to what he termed the 'learning-based industrialisation' adopted by countries such as Thailand and Malaysia, introducing innovations developed elsewhere.

This paper analyses current Malaysian IR at the workplace level posing the question as to whether the economic progress towards 'Vision 2020' is being accompanied by a 
transformation of Malaysia's IR. We will begin with an outline of our methodology. We then overview Malaysia's economic development, summarise Malaysian IR as it has been viewed in the past, and report on a series of studies of IR at the industry and firm level.

\section{Methodology}

Our research was undertaken as part of a larger project on globalisation and employment relations in Asia, conducted by a group of researchers across a number of countries under the auspices of the International Labour Organization. Fieldwork for this study was undertaken in August 1998 and March 1999, and therefore the period covered by this study followed after the financial crisis that hit much of Asia in the second half of 1997. The financial crisis added an extra dimension to the context within which IR was being viewed, providing an opportunity to clearly identify corporate preference: cost cutting strategies versus long-term commitment-oriented approaches or perhaps a combination of both.

Interviews were conducted with officials from national and industry level organisations, employer associations and unions. We then adopted a case study approach conducting a series of 16 case studies across four industries: banking, automobile and components manufacturing, electronics manufacturing, and hotels. The car and electronics industries have played critical roles in Malaysia's industrialisation whilst banking and hotels are important components of the services sector which Malaysia seeks to develop. Participant firms were selected to ensure a range of case studies but bearing in mind that we were looking for evidence of transformation of IR practices; thus the cases are a mix of union and nonunion workplaces; mostly 'leading edge' companies or companies with reasonably strong market positions, and a mix of foreign-owned and local ventures.

Data were collected through structured interviews and documentary material such as annual reports, collective agreements (CAs), was obtained from most organisations. To maintain confidentiality, we have used fictitious names for the companies concerned. In reporting the research findings we will focus on: work organisation; employee participation and control; training; compensation; labour/management relations; and employment security and the use of labour adjustment mechanisms.

\section{Economic Development}

Malaysia's industrialisation has been proceeding at a rapid rate for the past two-three decades with manufacturing's share of GDP increasing from 12 per cent in 1970 to 36 per cent in 1997. (Malaysia 1976; Ministry of Finance 1998). Industrialisation began with import substitution, turning in the late 1960s and early 1970s to a low cost export-oriented industrialisation (EOI) strategy. With rising productivity and wages, Malaysia shifted to a higher value-added EOI strategy in the mid 1980s and set its objective of becoming a developed country by 2020 .

Malaysia has relied heavily on foreign investment to achieve its rapid industrial growth and in the process has become dependent upon foreign capital, expertise and market access for its economic success. Within the manufacturing sector, foreign firms accounted for 44 per cent of manufacturing value added and 76 per cent of manufactured exports in 1992 (Ramstetter 1996, cited in Hill and Athukorala 1998:24). In Malaysia's drive to developed country status, the government is looking to MNCs as purveyors of sophisticated production techniques and processes and accompanying management practices to assist the country to be competitive.

Prior to the recent financial crisis the Malaysian economy was enjoying high growth (averaging 8.7 per cent in the period 1992-96), low inflation (3.8 per cent over 1992-96) and low unemployment (2.5 per cent in 1996). In mid 1997 the Malaysian economy was severely affected by a sharp depreciation of the ringgit. The ensuing economic crisis resulted in a serious downturn in business activity and a slump in GDP growth rates from 8.0 per cent in 1997 to -5.0 per cent in 1998. Unemployment rose from 2.6 per cent in 1997 to 4.9 per cent in 1998 ( Ministry of Finance 1998: 1xi). It appears that Malaysia has now past the worst of the financial crisis with forecasts suggesting a gradual return to (initially subdued) economic growth. 


\section{Industrial Relations}

Union influence in Malaysia has been circumscribed by laws pertaining to union recognition, the definition of issues subject to bargaining, freedom to strike and dispute resolution (Kuruvilla 1993; Jomo and Todd 1994). Union size and structure is heavily regulated through laws administered by the state; unions may not operate across industries, and industries are narrowly defined to minimise union reach and size (Arudsothy and Littler 1993), leading to a proliferation of small unions. In 1996 there were 516 unions accounting for approximately 9 per cent of employees. Due to state intervention some 42 percent of union members were covered by in-house unions (IHUs) in 1992 (BILA 1995:11).

The Malaysian Government has not ratified ILO Convention 87 guaranteeing freedom of association. Employer opposition to unionisation of workplaces has been widespread and the state has been reluctant to challenge such opposition, leaving workers unprotected against those employers refusing to recognise legitimate claims for union coverage. An array of tactics has been used by employers to prevent unionisation of their workplaces including indefinitely delaying union recognition applications, victimisation or promotion of activists to remove them from the shopfloor, and the formation of companysponsored unions (Jomo and Todd 1994).

Most Malaysian unions are involved in collective bargaining although employee coverage varies between industries. Overall, during 1994-1996 just 6 per cent of workers were covered by new CAs (MHR 1997:139). Despite a legal framework that purports to enable collective bargaining, the basic thrust has favoured managerial unilateralism. Legislation restricts the range of issues encompassed by collective bargaining.

Historically the union movement has had moments of militancy but since the late 1970s strike action has been reduced to the point of insignificance in Malaysian IR. In 1996, nine strikes occurred involving 995 workers, with an average duration of just over two days (MHR 1997:130). The government and employers have successfully repressed strike action deterring workers from using this form of industrial action. Throughout the history of the contemporary Malaysian unions there have been many instances of employers replacing striking employees or alternatively closing their workplaces temporarily. Legislation makes it very difficult for unions to organise legal strikes, with the potential consequences including union deregistration and detention of activists. In some instances, labour has responded to the repression of legal industrial action by taking unofficial action, either individually or collectively. Instances of unofficial go-slows, unavailability for overtime, increased medical leave and even vandalism have been cited by management and union leaders and management acknowledges that workers will simply resign when discontented. Some researchers have identified instances of conflict being expressed through covert mechanisms such as 'mass hysteria' and 'spirit possession' (Smith 1994:45).

As Malaysia's industrialisation focus shifted to a higher value-added EOI strategy the government implemented a range of policy measures aimed at promoting skill development including the establishment of the Human Resources Development Fund (HRDF) to which employers were required to contribute (Kuruvilla 1996). In addition, there was State encouragement for more commitment-oriented HRM practices with the Japanese model particularly singled out for praise and emulation (Smith 1994:14). However, there has been very little change to two tenets of Malaysia's IR policy - the provision of a plentiful supply of cheap unskilled labour and the maintenance of tight restrictions on labour's ability to bargain within the workplace. The government has continued to ensure a ready flow of cheap labour by firstly, allowing the importation of hundreds of thousands of temporary migrants from Indonesia and Bangladesh and secondly, by showing little commitment to raising the real wage levels of unskilled workers. ${ }^{1}$

\footnotetext{
${ }^{1}$ This could be compared to Singapore where unit labour costs were deliberately increased by 40 per cent in a six year period to coincide with their drive to encourage technology-intensive industry.
} 


\section{Banking}

We turn now to our case studies. Until recently Malaysia had 38 banks, including 14 foreign banks. The banking sector has survived the economic crisis but many banks incurred serious losses and the government now aims to reduce the number of banks to between eight and ten.

We conducted four banking case studies: Western Bank, owned by a western multinational corporation (MNC); Bank East Asia, owned by an east Asian MNC; Conglomerate Bank, owned by a Malaysian MNC; and Local Bank, Malaysian owned. Each employed 1900 to 2500 employees.

There are ten unions in the banking industry in peninsular Malaysia: two industry unions, and eight IHUs. (Separate unions exist in Sabah and Sarawak.) In all peninsular banks, clerical and related employees are represented by the National Union of Bank Employees, Peninsular Malaysia (NUBE). Officers are generally represented by the Association of Bank Officers, Peninsular Malaysia (ABOM). The NUBE is a large and, by Malaysian standards, a highly successful union in representing its members interests (see Peetz and Todd 1999b). Management in each of our four case studies recognised the need to gain the union's approval before implementing change and worked to ensure a close relationship with the union's leaders. The NUBE's ability to lead its members to accept change but also to mobilise them against unwanted change in turn gave it credibility and considerable negotiating power in dealing with the banks. It therefore has cooperative or at least accommodative relationships with all the banks studied.

During the economic crisis there had been no forced retrenchments. Those redundancies which had occurred had been achieved through voluntary separation schemes (VSS). There was little evidence from our case studies of outsourcing with only Western Bank outsourcing its information technology function. The NUBE had inserted cost barriers into the CA which had been successful in deterring the banks from employing part-time or casual employees, thus almost all employees had permanent full-time status.

Work still seemed to be organised along broadly traditional lines. The main impetus for change has been the introduction of new technology, although many of the banks still have a considerable way to go before they feel the full effects of technological change. Bank East Asia had been multiskilling employees over the preceding two years, Western employees were multiskilled whilst the other two had not implemented multiskilling. Western had implemented the most significant change in work organisation by weakening the boundaries between 'front office' and 'back office' employees.

The banks have been slow to embrace the concept of worker empowerment. The main evidence of employee participation was in occasional problem solving or goal setting exercises. Again it was Western Bank who led the way here having extended clerical employees' autonomy by increasing their authorisation limits to a level previously applying to officers, an action which was referred to as 'empowerment' by both the Bank and the union. Western had been extending teams, many of which may have clerical employees as team leaders. Local Bank and Bank East Asia had introduced the team concept to their employees but teams were barely functioning.

Malaysia's central bank requires banks to spend the equivalent of at least 2.5 per cent of salary costs on training. Moreover banks who poach employees above a certain grade from other banks must pay a sum equivalent to six months salary into an industry fund. For these reasons, and because of the nature of the industry, the banks devote considerable resources to training. They typically have their own in-house training schools that provide specialised, often modularised, induction for new recruits and training for ongoing employees. Conglomerate Bank had increased their training during the economic downturn and was currently spending 4.5 per cent of its payroll on it. Training at Western was standardised internationally across the multinational group and then determined at an individual level through personal development plans.

Compensation is structured similarly across most banks, reflecting the influence of two industry CAs, though there is some variation at the margin. As in many Malaysian firms, remuneration is primarily based on a seniority-related increment system. Partly as a consequence of the emphasis this gives to seniority over performance, banks, like many other 
Malaysian firms, pay staff bonuses. However, the flexibility these provide is limited by employee expectations of regularity in pay. Hence both CAs provide for a minimum bonus equivalent to two months salary. Some banks, including all four in our study, had recently introduced annual contingent bonuses based on the performance of the bank and the individual. Though a source of flexibility, their implementation encountered problems including perceptions of unfairness amongst staff over the size of individual payments and resentment over non-payment in 1998 due to the economic slump. Western had introduced performance-related pay for mid-level officers and management and wished to extend this to clerical workers.

\section{Hotels}

The Malaysian hotel industry has been growing rapidly leading to oversupply of rooms. Between 1992 and 1995 the number of rooms grew from 45,000 to 95,000, and employment rose from 40,000 to 69,000 (Malaysia 1996:505). However, average occupancy rates fell from 73 per cent in 1992 to 50 per cent in the first half of 1998 (Ministry of Finance 1998:91).

We undertook three hotel case studies: Fourstar Hotel, owned by a Malaysian conglomerate; Resort Hotel, part of a Hong Kong-based MNC conglomerate; and Fivestar Klang, Malaysian owned but managed by an American MNC Fivestar chain. They employed 300, 900 and 370 employees respectively. Because of its market positioning, Resort Hotel's occupancy rate had increased during the economic downturn, but the other two had suffered 50 per cent revenue slumps.

Most large hotels in the main urban areas are unionised. Although there are a small number of IHUs (including one in Fourstar) most hotels are covered by the industry union, the National Union of Hotel, Bar and Restaurant Employees. Fourstar's IHU has minimal resources and is acquiescent to management's initiatives. It is the main communication vehicle between management and workers and the most commonly discussed issue within the union at the time of our visit was how to increase the hotel's business. Fivestar and Resort both had industry union coverage - with about 95 per cent density in Resort and 50 per cent in Fivestar amongst eligible employees. The management/union relationship at both hotels was co-operative. Management saw the union as having a valuable role in communicating and persuading members of management's intended changes, but at Resort the union was blocking some moves to multiskilling and in Fivestar the union was seen as an obstacle to performance-pay and had prevented pay cuts in the recession.

Implementation of management systems that ensure consistent quality of service and increase productivity is very uneven across the Malaysian hotel sector and in the developmental phase for many. Fourstar had not attempted to implement any such systems. On the other hand, Fivestar had set procedures and standards for every department - the Fivestar Guest Service Standard, a multinational group benchmark - which required employees to achieve four levels of certification. They also benchmarked their performance, including labour productivity, against a set of measures known as OP10. At Resort, HR management were considering ways to increase productivity including self-empowered work teams as well as measures that would appear to involve work intensification.

There were signs of moves towards functional flexibility through multiskilling in all the case study hotels but it had been completed in none, with Fivestar having gone the furthest in this regard. Within Resort there was some multiskilling and employee mobility but fears of work intensification had led to union opposition to its extension.

There was no evidence of any employee participation schemes within our three case studies. Centralised hierarchical decision-making was still very strong. Resort reported that it was trying to develop a participative management style but found employees reluctant 'to speak up'.

Until recently training has been a very low priority within hotels. It was not until 1995 that the government extended the HRDF to the industry. At a national level, development of occupational skills standards for the hotel industry has begun but many areas have yet to be addressed. Training is treated unevenly between the hotels with the overseasbased MNC hotels giving it the highest priority. In all cases it appears the HRDF has 
increased the focus, and probably the resources, devoted to training. Fourstar accepted it was a necessity but considered it a financial burden and had reduced their training expenditure during the economic downturn.

Remuneration in the hotel industry, like elsewhere, is principally determined by classification and tenure with the pay scales having annual increments. A substantial part of employees' remuneration flows from the service charge which is also allocated according to tenure and classification but which fluctuates with the hotel's performance. Fourstar, with an IHU, paid a profit-based contingent bonus but no contractual bonus; Resort had both types of bonus; while Fivestar had a contractual bonus and had abandoned ideas of performance related pay (based on individual performance) in the light of angry employee reactions within a 'sister' hotel.

Employment levels had declined through attrition in Fourstar and Fivestar. There had only been two employees retrenched within the three case studies, a result of Fourstar's decision to close their carpark and the attendants' refusal to be redeployed. There had, however, been a substantial increase in dismissals at Fivestar and in discipline cases at Resort during the past year, suggesting management was taking advantage of the weaker labour market. Very little work was contracted out.

\section{Automobile and Component Manufacturing}

The Malaysian car industry is dominated by the national car project - Proton - which was established as a joint venture between the Malaysian government and Mitsubishi and commenced production in 1985. In 1998 Proton held 68 per cent of the domestic market (Proton 1998:19). However, the automobile industry was one of the two sectors most badly hit by the economic downturn associated with the financial crisis. In 1997 314,000 new cars were sold; this decreased to 138,000 in 1998 (Australian Financial Review 22 April 1999).

Our choice of five case studies reflects different sectors of the Malaysian auto industry. Volume Car Company (VCC) is a plant within the national car company. Quality Assembly Bhd (partly overseas-owned but largely autonomous) and Midrange Assembly Bhd (a Malaysian family firm) are two of the major assemblers, each building cars for several overseas manufacturers. Brake Bhd (an Australian MNC) and Glass Bhd (a MalaysianJapanese joint venture) are two suppliers to the industry: the former is highly dependent on the national car project; the latter supplies the national car project but also has other purchasers across and outside of the auto industry.

There was very little evidence in the factories we visited of the advanced lean production techniques more typical of the international car industry. In particular, VCC is still a long way from being internationally competitive. Japanese influence was apparent in the establishment of active quality circles (QCs) at VCC, Quality and Glass, the adoption of the $5 \mathrm{~S}$ program by Midrange and Glass and the consideration being given to the introduction of JIT in two of the factories. However, the organisation of the work was relatively Tayloristic with limited multiskilling taking place. The most advanced work organisation was perhaps at Brake where teams had been formed and remuneration was directly related to skill acquisition. At Quality and Glass there was limited multiskilling but at VCC and Midrange workers were allocated to a single task indefinitely.

A high level of managerial prerogative was evident in all five workplaces. The only one in which the union appeared to have any form of genuine input outside of agreementmaking was Quality. The employees at Quality and Glass belonged to industry unions, there were weak IHUs at VCC and Midrange, Brake was non-union. The unions were viewed by management as providing an important communication function particularly when it came to the implementation of change. While the union presence served as a check on management's intentions there was little evidence of them seriously challenging management's decisionmaking role. Nonetheless, both VCC and Glass had encountered more problems than previously with the renegotiation of their CAs. At the time of our visit both negotiations were 'deadlocked', with the Glass agreement having been referred for arbitration.

Remuneration is determined through CAs in the four unionised plants but unilaterally by management at the non-unionised Brake. VCC's employees had been among the best paid 
manufacturing workers prior to the financial crisis but their total remuneration had declined 35-45 per cent mainly due to the removal of overtime. Pay at VCC, Quality and Brake included a bonus contingent upon the company's performance while Brake's increment system was based on skill acquisition rather than length of service. The weakness of the IHU at VCC is reflected in the fact that it has been unable to deliver a contractual bonus for its members.

At Quality the union enables employees to have some input into workplace decisionmaking. This was particularly evident in the planning prior to last year's temporary paid layoff of employees (see below). Brake has a Joint Consultative Committee but similar to the unions in the remaining three workplaces it does not challenge management's unilateral decision-making. These function principally as communication forums as well as providing the opportunity to resolve minor disputes involving issues such as safety and disciplinary matters.

Much emphasis is placed on training in both the suppliers studied and in VCC, with specialist training being provided by Japanese joint venture partners in VCC and Glass. At Brake a skill matrix has been developed for operators and team leaders follow a standard format in providing on-the-job training. While VCC claims to spend the equivalent of ten per cent of the cost of salary on training, production is organised so that the workers continue to perform the same task on the line indefinitely. Training has not been a high priority with the two assemblers in the past although it is growing in importance at Quality.

All five factories had reduced their workforces due to the severe downturn in demand with the economic crisis but the only compulsory retrenchment of local employees had occurred at Brake where management viewed it as 'good management' to downsize early in the crisis. This contrasted sharply with management's attitude in the other four plants who all regarded it as unacceptable to retrench their local employees. Peripheral employees, however, did not enjoy the same consideration; 100 local contract employees did not have their contracts renewed at Midrange, while Glass and Midrange retrenched 200 and 350 foreign employees respectively. A more innovative response to the downturn in production was adopted by Quality and Midrange, both closed their assembly plants for three months laying off their employees temporarily but continuing to pay them 75 per cent of their base pay.

The economic downturn had resulted in labour dissatisfaction in at least two of the workplaces we visited; at Brake management's decision to retrench 28 out of 85 employees was viewed dimly and there had been 800 resignations at VCC due to the substantial decrease in remuneration.

\section{Electronics}

Much of Malaysia's industrial development emanated from the growth of the electrical and electronics industry, this sector accounts for 37 per cent of manufacturing output and is the largest export sector. The semi-conductor industry, being influenced by global rather than domestic trends, suffered only a slight decline in 1998. Foreign MNCs dominate this sector and our four case studies are all MNC-owned. Three of the companies we studied - Micro, Drive and Elecomp - make components for computers while the fourth - Nippon Electronics (NE) - produces cathode ray tubes for televisions and monitors. The four workplaces ranged from 1800 to 5500 employees.

The degree of influence of parent companies varied significantly across our four case studies. Two of the four are part of major global corporations. In one of them, Micro, the parent company is clearly responsible for driving the HR/IR policy and other activities in Malaysia. In the other, NE, the parent company's influence is mainly in the technical and accounting areas. Its HR/IR philosophy is critical in such areas as the 'no retrenchments' policy and the approaches to training and morning assemblies, but it has not had much involvement in more day to day HR/IR matters. In our other two cases, the parent company has had little influence on HR.

Within our case studies much of the work organization was Tayloristic - within Elecomp and Drive operators performed a single task repetitively although Drive gave them 
the opportunity to transfer, after training, to another task quite regularly. Only in Micro have highly automated systems replaced production lines relying on either manual dexterity or heavy labour. In most cases QCs have been used, though in Elecomp they were aborted, after corporate focus shifted from quality to quantity once a key change agent moved on.

The Malaysian electronics industry is notoriously non-union, a combination of the demands of capital (particularly from the US) and State regulation. Our four case studies were no exception. Only in NE were formal representative structures established as an alternative to union representation and except for the safety committee these did not deal with mainstream workplace relations concerns anyway. ${ }^{2}$ All four companies relied on mass assemblies, ad hoc lunches involving the managing director and rank and file employees, or the HR function itself, to transmit the employees' concerns to management. Within the Malaysian workplace culture, where managerial prerogative is presumed by employees, it is difficult to envisage these ad hoc mechanisms providing effective employee input.

There was a high level of emphasis on training within three of the four workplaces visited. Both Micro and NE send selected employees to corporate training centres overseas. By comparison Elecomp's training was mostly confined to supervisors and managers and was partly driven by the requirements of the HRD Fund.

Remuneration is unilaterally determined by management. The lack of union input was evident in the greater use of contingent pay increments and contingent bonuses. Formal performance appraisal processes were in place in all four case studies. Local employer networks help shape remuneration practices and employer surveys communicate norms in wage increases.

Elecomp had reduced its workforce by $800(30 \%)$ earlier in the year through voluntary separation. NE was committed to a policy of 'no retrenchments' while Drive had avoided them as a result of in-sourcing activities previously undertaken more inefficiently in the Philippines. Micro's market growth meant it had not been faced with the issue.

\section{Conclusion}

If our question is simply whether Malaysia's economic development drive was being accompanied by fundamental changes in IR, the short answer would be 'No'. State intervention remains pervasive, managerial control in the workplace continues to dominate and labour's ability to bargain collectively remains restricted.

The situation, however, is not static. First, the emphasis on training has grown substantially and this was reflected within the workplaces we visited. The quality of the training being provided varies with some companies having more sophisticated approaches e.g. curriculum-based on needs analyses - and others being more 'ad hoc'. Second, the implementation of multiskilling is progressing, although it was occurring in no more than half of our case studies and was typically incomplete. There are examples of companies adopting some 'lean production' practices, such as the development of work teams, but these would still appear to be isolated instances.

The aspect of IR which remains so obviously unchanged is the fundamental issue of control and decision-making within the workplace. Genuine consultative mechanisms have not been introduced. Where JCCs do exist - such as at Brake and NE - their role is limited to peripheral matters and may be being used to deflect interest in union formation. The unions are viewed as useful communication vehicles by management, helpful in persuading the workers when change is being implemented. However, while relations are typically accommodative, management do not have it all their own way, at least in some of the workplaces with industry unions. Some managerial initiatives are being blocked by unions. We encountered meaningful union input into the decision-making process at Quality and via the NUBE within the banking industry. While the restrictions which remain in place on union activities continue to ensure that unions do not pose a serious challenge to managerial

\footnotetext{
${ }^{2}$ The JCCs included the Sports and Recreation Committee, the Big Sisters Committee (inactive), the newsletter committee, the canteen committee, the Muslim employees association, the technical skills committee, the suggestions committee and the housekeeping group.
} 
prerogative, in banking in particular they are still influential. By contrast, though the power and independence of the IHUs varied, none demonstrated the capacity to represent members effectively.

The philosophy underpinning remuneration also remains fairly stable despite the government's promotion of contingent remuneration systems. Many companies include a performance-related bonus within their pay packages but the bulk of an employee's pay continues to be based on the wage for the occupation, tenure-related increments and a contractual bonus.

How is state policy influencing current Malaysian IR? The answer is, with ambivalence and contradictions. On the one hand, the state wishes to promote higher skills and productivity. The HRDF and various other initiatives appear to have been very successful in enhancing the resources devoted to training and skills development. On the other hand, low-skilled and low-productivity jobs have been perpetuated by the ready supply of foreign labour, which has retarded wages growth. This has eased the pressure on firms to develop skills and introduce more productive techniques and slowed the restructuring towards higher-wage, higher-productivity industries.

There is also ambivalence in the treatment of unions. On the one hand, the government has shown signs of shifting from what had been widely seen as an antagonistic or exclusionist approach towards unions. There have been recent attempts to incorporate unions into national decision making processes through such mechanisms as the National Economic Advisory Committee and various conciliatory gestures in the context of economic crisis and political instability (Peetz \& Todd 1999a). On the other hand, much of the state policy and restrictive legislation regarding unions remains in place, having been an integral part of the State's strategy to attract investors during the low-cost, labour intensive EOI phase of Malaysia's industrialisation and having not, to date, been properly reconsidered.

What, then, are the forces for progression and for recidivism in Malaysian IR? It would be difficult to say that the logic of industrialisation is leading inexorably to the "new IR'. State policies, which are integral to industrialisation, are simply not consistent enough in that regard. The perceived need to continue to attract multinational capital makes the government wary of withdrawing the restraints on labour. In this sense, globalisation, actively courted by the Malaysian state, may be retarding the shift to the new IR. At the same time, however, MNCs are often the transmission mechanism for new ideas and practices on $\mathrm{HR}$, including in training, systems and work organisation. Thus globalisation itself is having an ambiguous impact on IR development.

But one should not underestimate the influence of domestic considerations. The financial crisis may have been a consequence of globalisation but there was a particular Malaysian response to the crisis. We have already mentioned some national responses. At the workplace level, the economic crisis provided an opportunity to identify whether employers were adopting long-term commitment-oriented approaches, which might be evidence of some greater embracing of the 'New IR'. Here the results were mixed but on balance slightly encouraging. Compulsory retrenchment of Malaysian workers had occurred in only one of the 16 workplaces we visited, suggesting a commitment-oriented approach. There appeared to be, for the moment at least, efforts to engage unions more in negotiating change. Indeed, management espoused strong moral responsibility to avoid retrenching workers. However, there were also cost-related factors which made managers hesitant to downsize: the high cost of retrenchments due to government regulations; and the previous tightness of the labour market suggesting future recruitment may be expensive. Some companies retrenched foreign workers, whose plight was of little interest to many Malaysian workers. The commitment engendered by 'no retrenchments' policies was tempered by the loss of income caused by cuts to overtime and, where relevant, bonuses and even increments. Again, we have yet to see whether tentative moves towards stronger commitment approaches are cyclical or permanent.

Finally, the tight labour market prior to the economic crisis had given labour one vital control mechanism: the ability to change employers. High levels of labour turnover were endemic to the Malaysian workplace and while turnover has reduced because of the economic 
downturn, it can be expected to increase again as the economy picks up. This may be the strongest element of continuity of them all.

\section{References}

Appelbaum, E. and R. Batt (1994) The New American Workplace - Transforming Work Systems in the United States. Cornell: ILR Press.

Ariff, Mohammed, Chung, M.Y.H., Kadir, A.W.A., Ean, O. G, \& Lae-Imm, E. T. (1998) Currency Turmoil and the Malaysian Economy: Genesis, Prognosis and Response, Kuala Lumpur: Malaysian Institute of Economic Research.

Ariffin, Rohanna (1997) 'Changing Employment Structures and Their Effects on Industrial Relations in Malaysia', Economic and Labour Relations Review 8 (June):44-56.

Arudsothy, P \& Littler, C (1993) 'State Regulation and Union Fragmentation in Malaysia', in S Frenkel (ed) Organized Labor in the Asia-Pacific Region: A Comparative Study of Trade Unionism in Nine Countries, Ithaca:ILR Press.

Australian Financial Review 22 April 1999.

Bureau of International Labor Affairs (BILA) (1995) Foreign Labor Trends: Malaysia, FLT, Department of Labor, Washington.

Deyo, F. (1995a) 'Human Resource Strategies and Industrial Restructuring in Thailand' in Frenkel, S. \& Harrod, J. Industrialization and Labor Relations: Contemporary Research in Seven Countries, Ithaca: ILR Press.

Deyo, F. (1995b) 'Capital, Labor, and State in Thai Industrial Restructuring: The Impact of Global Economic Transformations' in D.A. Smith and J. Borocz (eds) A New World Order? Global transformations in the Late Twentieth Century, Westport:Praeger

Hill, Hal and Athukorala, Prema-chandra (1998) 'Foreign Investment in East Asia: A Survey', in Asian-Pacific Economic Literature, 12(2), 23-50.

Jomo, K.S. and Todd: (1994) Trade Unions and the State in Peninsular Malaysia, Kuala Lumpur: Oxford University Press.

Kitay, J. (1997) 'Changing Patterns of Employment Relations:Theoretical and Methodological Framework for Six Australian Industry Studies' in Kitay, J. and R. Lansbury (eds) (1997) Changing Employment Relations in Australia. Melbourne: Oxford University Press.

Kochan, T.; H.Katz and R. McKersie (1986) The Transformation of American Industrial Relations. New York: Basic Books, Inc

Kuruvilla, S (1996) 'Linkages Between Industrialisation Strategies and Industrial Relations/Human Resource Policies: Singapore, Malaysia, the Philippines, and India', Industrial and Labor Relations Review 49, July, 635-57.

Kuruvilla, S (1993) 'Industrialization Strategy and Industrial Relations Policy in Malaysia', in S Frenkel and $\mathbf{J}$

Harrod (eds) Industrialization and Labor Relations: Contemporary Research in Seven Countries, ILR Press, Ithaca, 216-235.

Malaysia, (1976), Third Malaysian Plan 1976-1980, Kuala Lumpur. , (1996) Seventh Malaysia Plan 1996-2000, Kuala Lumpur

Ministry of Finance (1998) Economic Report 1998/99, Kuala Lumpur.

Ministry of Human Resources (MHR) (1997) Malaysia: Labour and Human Resource Statistics 19921996, K.L.

Peetz, D. \& Todd: (1999a) 'Responding to Crisis: Implications of the Asian Experience', paper to sixth national conference on unemployment, University of Newcastle, September.

Peetz, D. and Todd: (1999b) 'Otherwise You're On Your Own': Unions And Bargaining In Malaysian Banking'

Piore, M. and C. Sabel (1984) The Second Industrial Divide: Possibilities and Prosperity. New York: Basic Books.

Proton (1998) Annual Report

Rasiah, R. (1995), 'Labour and Industrialization in Malaysia' in Journal of Contemporary Asia, 25(1): 73-92.

Smith, W. (1994) 'Japanese Enterprises and Industrialisation in Malaysia: Japan's Contribution to the Impact of Globalisation on Malaysian Industrial Workers', Hiroshima Journal of International Studies, 2, Mar, 39-56. 